\title{
Development and Validation of a Reading Self-Efficacy Scale
}

\author{
Gulten Kosar(i) ${ }^{*}$, Yunus Emre Akbana (iD) ${ }^{2}$, Levent Yakar ${ }^{3}$
}

\author{
${ }^{1}$ Hatay Mustafa Kemal University, Faculty of Edu., Dep. of English Lang. Teaching, Hatay, Turkiye \\ ${ }^{2}$ Kahramanmaras Sütçü Imam University, Faculty of Edu., Dep. of English Lan. Teac., Kahramanmaras, Turkiye \\ ${ }^{3}$ Kahramanmaras Sütçü Imam University, Faculty of Edu., Dep. of Edu. Sciences, Kahramanmaras, Turkiye
}

\section{ARTICLE HISTORY}

Received: Mar. 10, 2021

Revised: Nov. 20, 2021

Accepted: Jan. 24, 2022

Keywords:

College students,

English language teaching,

Reading self-efficacy.

\begin{abstract}
Reading self-efficacy performs a fundamental role in gaining academic achievement in college education. Review of the related literature unveils that it needs to be enriched by conducting further research on college students' reading self-efficacy. The paucity of investigations into college students' reading selfefficacy could have a connection with the lack of a comprehensive reading selfefficacy scale targeting exclusively measuring it. For this reason, this study aims at developing and validating a reading self-efficacy scale which could be used to measure college students' reading self-efficacy. The data was collected from three distinct groups consisting of a total of 430 students of the departments of English language teaching and English language and literature studying at state universities in Turkey. The findings obtained from exploratory factor analysis revealed that the scale had a unidimensional structure and the ones provided by confirmatory factor analysis confirmed the structure of the scale. The developed and validated 16-item reading self-efficacy scale could prompt the university teachers of reading to undertake studies with an eye to examining their students' reading self-efficacy.
\end{abstract}

\section{INTRODUCTION}

Reading comprehension is a fundamental skill to achieve success at tertiary level (Meniado, 2016). A reader's prior knowledge (Kintsch, 1998), cognitive skills and repertoire of reading strategies (Duke \& Pearson, 2002), reading proficiency (Mills et al., 2006), the text, reading context and motivation (Afflerbach \& Cho, 2010), and the online/offline reading modes (Forzani et al., 2021) are among the determining factors in comprehending a reading. Being literate in a second language (L2) or foreign language (FL) requires an individual to overcome several challenges as opposed to reading in L1 due to the intricacies of L2/FL reading and the complex cognitive processes (Graham et al., 2020; Murad Sani \& Zain, 2011). For example, linguistic, affective and motivational factors affect reading comprehension in L2/FL (Grabe \& Stoller, 2019; Li \& Wang, 2010). Additionally, other key factors such as comprehension strategies (Taylor, 2014), language proficiency (Fung \& Macaro, 2019), self-regulatory reading strategies (Macaro \& Erler, 2008), self-efficacy and strategy use (Zimmerman, 2013), and strategy instruction for developing self-efficacy $(\mathrm{Gu}, 2019)$ are vital to reading achievement in L2/FL (Graham et al., 2020).

\footnotetext{
${ }^{*}$ CONTACT: Gülten KOŞAR $\bigotimes$ gulten.kosar@mku.edu.tr $\equiv$ Hatay Mustafa Kemal University, Faculty of Education, Department of English Language Teaching, Hatay, Turkiye
} 
Achievement in reading is pertinent to reading self-efficacy (Tavakoli \& Koosha, 2016). The association between these two constructs becomes perfectly clear considering the positive correlation between them; that is to say, the higher one's reading self-efficacy, the higher their reading achievement is (Hedges \& Gable, 2016). High level of self-efficacy is revealed to contribute to learners' growth in reading (Capara et al., 2008). Several studies have reported the higher self-efficacy beliefs, the better results in developing reading comprehension (Bağc1, 2019; Barkley, 2006; Cho et al., 2015; Forzani et al., 2021; Hedges \& Gable, 2016; McLean \& Poulshock, 2018; Peura et al., 2019; Ronimus et al., 2020; Soland \& Sandilos, 2020; Tremblay \& Gardner, 1995; Unrau et al., 2018). Basically, attitudes towards reading could influence reading self-efficacy of an individual; for instance, individuals who enjoy reading are shown to have higher levels of reading self-efficacy in comparison to the ones not enjoying reading (Burrows, 2012; Carroll \& Fox, 2017).

Efficacy beliefs can range from weak to strong due to the specificity and the level of task difficulty (Bandura, 1997). Self-efficacy is defined as an individual's own judgments of their perceived self-capabilities to perform tasks or actions at the designated levels (Bandura, 1997; Schunk, 2003). According to Unrau et al. (2018), reading self-efficacy is "readers' perceptions of competence in their ability to successfully complete reading tasks" (p. 168). To measure reading self-efficacy, Carroll and Fox (2017) argue that there is still a strong need for "... a specific single measure of reading self-efficacy" (p. 2) because previous studies do not purely focus on such a single measure of self-efficacy. As Bandura (1997) outlines, three levels of specificity exist to be resorted to in the measurement of efficacy beliefs: general, intermediate and specific. The specificity level of general refers to the general beliefs of one's efficacy and the specificity level of intermediate describes the performances under a domain of activity while that of specific addresses the completion of specific tasks. Drawing on Peura et al.'s (2019) study evaluating specificity levels of reading self-efficacy scales, it could be argued that the scale this study develops falls into the specificity level of intermediate. Furthermore, to prepare a good self-efficacy scale, Bandura $(1997,2006)$ suggested several principles. To list, the items should be phrased in a clear and unambiguous language; written in the form of can do statements; prepared for a specific domain with the content of tasks; challenging to avoid ceiling effect; asking one's competences; arranged randomly or from the least to the most challenging employing content focusing on beliefs rather than self-worth, locus of control or outcome expectancies; and further, it should employ predictive power by testing what it intends to measure and include only necessary sub-skills or one operative efficacy.

There have been studies extensively focusing on L1 reading self-efficacy and its relation to reading attitudes and reading motivation (Hedges \& Gable, 2016). For example, Ghonsooly and Elahi (2010) investigated the relationships among reading self-efficacy, reading anxiety and reading achievement. To do so, the authors designed a reading self-efficacy scale based on three other scales available in the literature and adapted it in Persian language. The scale had 11 items with a four-factor structure involving the dimensions of students' ability in reading English texts, student's inability in reading English texts, practice and skill and enjoying group work. The Cronbach's alpha coefficient for their scale was satisfying $(\alpha=0.78)$, but the number of participants was only 150 second-year college students. In addition, Peura et al. (2019) developed reading self-efficacy and reading comprehension scale for young learners, focusing on reading fluency. There are also several studies measuring L1 reading self-efficacy construct in Turkish context. For instance, Kula and Budak (2020) developed a scale to measure reading self-efficacy perceptions of 525 primary school students. The scale had a single-factor structure and consisted of 29 items written in the form of can do statements. The scale was designed as a 3-point ikert scale rather than a 5-point one. Besides, Karabay (2013) developed "Critical Reading Self-Efficacy Perception Scale" with the participation of 650 pre-service Turkish language teachers. The scale involved 41 items with three sub-dimensions; evaluation, research, 
and visual themes. In addition, Şahin and Öztahtalı (2019) developed "Effective Reading SelfEfficacy Perception Scale" with 677 high-school students. The scale had a four-factor structure with the dimensions of comprehension, breathing, pausing and appearance, and consisted of 21 items with a 5-point Likert scale but not in the form of can do statements.

Regarding target language reading self-efficacy scales, Ahmadian and Pasand's (2017) scale, which was originally developed by Zare and Davoudi Mobarakeh (2011), is satisfactory with regard to content, validity and favorable particularly for L2/FL learners with intermediate level of English. Secondly, Kakaew and Damnet's (2017) reading self-efficacy scale is available in the literature but it does not align with Bandura's suggestions because the scale incorporates only three can do statements and measures constructs other than reading self-efficacy such as self-worth and locus of control. Thirdly, the reading self-efficacy scale used in Boakye's (2015) study was originally developed from the works of Grabe and Stoller (2002), and Guthrieet al. (2000). However, it might fail to measure reading self-efficacy because it addresses the common reading problems among students at risk of academic failure. Additionally, it fails to measure competency beliefs because it employs items focusing on self-worth rather than the context governing the challenge of the tasks. Fourthly, the scale used in McLean and Poulshock's (2018) study was originally developed by Burrows (2012), which fits into Bandura's guidelines except for its being developed with non-English major students. Finally, the L2 reading self-efficacy questionnaire developed by Mullins (2018) in Spanish aligns with Bandura's principles in that it employs can do statements, developed for a specific target group (viz. novice learners), involves unambiguous items, and has potentially rich response use (viz. 100-Likert scale) but Mullins (2019) criticizes the first 8 items which focus on the components of reading rather than the domain of reading self-efficacy.

Reading self-efficacy is a significant construct that needs to be measured accurately, bringing to the forefront the need for the instruments specifically developed to assess it. Review of literature on reading self-efficacy instruments prompted the researchers to conduct research to develop and validate an FL/L2 reading self-efficacy scale with an eye to measuring the level of reading self-efficacy of college students particularly majoring in foreign language teaching and literature departments. In view of the lack of a reading self-efficacy scale developed and validated through the participation of students at different years of study in the aforementioned majors, the deficiencies in the existing reading self-efficacy scales pinpointed in the preceding paragraph and the comprehensiveness of the items in the scale developed and validated in this study, it could be argued that this research could contribute a lot to the literature on reading self-efficacy in FL/L2.

\section{METHOD}

\subsection{Study Groups}

Three different data sets were collected from three distinct groups to perform exploratory factor analysis (EFA), confirmatory factor analysis (CFA) and test-retest reliability.

\subsubsection{First group}

The first group was comprised of a cohort of 180 participants in the selection of whom convenience sampling was used. $100(56 \%)$ of the participants were the students of English language teaching department and the remaining $80(44 \%)$ participants were the students studying at the department of English language and literature at four state universities in Turkey. $46(26 \%)$ of the participants were first-year students (female students $=28$, male students $=18$, mean age $=18.8) .50(28 \%)$ students in the first group were second-year students (female students $=31$, male students $=19$, mean age $=19.2)$, and $42(23 \%)$ students were thirdyear students (female students $=27$, male students $=15$, mean age $=21.2$ ), and the rest of the students in the first group were $42(23 \%)$ fourth-year students (female students $=25$, male 
students $=17$, mean age $=22.4$ ). Students' level of proficiency in English was not a parameter taken into consideration in choosing participants. The data collected from the first group was used for conducting EFA.

\subsubsection{Second group}

Second group involved 153 students of the departments of English language teaching and English language and literature studying at four state universities in Turkey, a group different from the first one and selected through convenience sampling. 38 (25\%) students were firstyear students (female students $=26$, male students $=12$, mean age $=18.7)$, and $44(29 \%)$ students were second-year students (female students $=28$, male students $=16$, mean age $=$ 19.8). $35(22 \%)$ students were third-year students (female students $=19$, male students $=16$, mean age $=21.1)$, and the remaining $36(24 \%)$ participants were fourth-year students (female students $=23$, male students $=13$, mean age $=22.8$ ). The data gathered from the second group was used for performing CFA.

\subsubsection{Third group}

Third group consisted of 65 (67\%) first-year and 32 (33\%) fourth-year students of English language teaching department studying at two state universities in Turkey (female students $=$ 70 , male students $=27$, mean age $=20.59$ ). Convenience sampling was used to select the third group participants, akin to the sampling used in the selection of the first and second group participants. The data collected from the group was analyzed to measure test-retest reliability coefficient.

\subsection{Data Collection Tool}

Since this study aims to design a reading self-efficacy scale with the participation of college students majoring at the departments of English language teaching and English language and literature, the development of the data collection tool was commenced by reading books on teaching reading (Blachowicz \& Ogle, 2008; Butterworth \& Thwaites, 2013; Carter, 2011; Dallon \& Ratner, 2002; Guthrie \& Taboada, 2004; McGuinness, 2005; Palincsar \& Brown, 1986; Smith, 2012). Aside from reading books on the teaching of reading, the questionnaires and scales having been developed to measure reading self-efficacy thus far and the research having been undertaken on reading self-efficacy were analyzed (e.g. Ahmadian \& Pasand, 2017; Barber et al., 2015; Boakye, 2015; Ferrara, 2007; Mullins, 2018; Peura et al., 2009; Solheim, 2011; Venegas, 2018). While reading the literature pertaining to reading self-efficacy, factor structures and response scales were reviewed in order to seek for potential dimensions. According to this review, only two studies mentioned the factor structure of the reading selfefficacy scale. Soolheim (2011) reported the reading self-efficacy scale had one dimension and 5-step Likert continuum (From 1 "I don't agree" to 5 "I agree") and Peura et al. (2019) identified a three-hypothetical-factor structure in the scale and related the dimensions to the general, intermediate and specific levels of specificity as outlined by Bandura (1997). Peura et al. (2019) used a 7-point scale for responses (From 1 "I'm totally certain I can't" to 7 "I'm totally certain I can"). The factor structure of the 5- point Likert scale (From 1 "Strongly agree", to 5 "Strongly disagree") in Ghonsooly and Elahi' (2010) study was found to include the dimensions of students' ability in reading English texts, student's inability in reading English texts, practice and skill and enjoying group work. A single-factor structure was identified in Kula and Budak's (2020) 3-point Likert scale (1 "Doesn't fit me", 2 "Fits me a little", 3 "Fits me completely"). Also, evaluation, research, and visual themes were detected in Karabay's (2013) 5-point Likert scale (From 1 "Never" to 5 "Always") and finally comprehension, breathing, pausing and appearance were presented to be the four dimensions in Şahin and Öztahtal1's (2019) 5-point Likert scale starting with "Always (1)" and moving towards "Never (5)". Nonetheless, in their examination of other scales, Peura et al. (2019) found that most of 
the reading self-efficacy studies did not report the factor structure and the level of specificity of reading self-efficacy scales. This encouraged the researchers to state the factor structure and specificity level of the developed and validated reading self-efficacy scale in this paper. Additionally, in light of the literature on reading self-efficacy, an item pool including 16 items in can do statements and 5-point Likert scale (Not at all (1), Slightly (2), Somewhat (3), Fairly well (4), Very well (5) was generated. The items were produced in light of Bandura's (1997, 2006) principles of developing items in a reading self-efficacy scale.

The generated items were e-mailed to three pre-service English language teacher educators teaching Reading Skills and Critical Reading and Writing courses for more than 10 years at three different state universities in an effort to ensure content validity. The teacher educators judged that all the constructed items served for measuring college students' reading selfefficacy and were adequate for accurate measurement of it. As a result of the expert opinions, the scale was administered to 20 students and the feedback collected from them indicated no need for amendments in the items (See Appendix). Once the ethical approval was obtained from Hatay Mustafa Kemal University Social and Human Sciences Research and Publication Ethics Board (document no. 902-01-FR 006), the data from three groups were collected first in the third week of October, 2020; then, data from the third group were gathered again in the first week of November, 2020 to perform test-retest reliability coefficient. The data were obtained through Google Forms ensuring students' anonymity and consent.

\subsection{Data Analysis}

The three distinct sets of data were subjected to a different analysis. First of all, data 1 was analyzed through performing EFA with a view to figuring out the construct/s measured by the scale and determining the scale items. Then, in order to verify the unfolded construct, CFA was performed on data 2. Finally, test-retest reliability analysis was conducted using data 3 to explore the stability of the confirmed scale through test-retest technique.

Outliers and normal distribution, the required assumptions for performing EFA, were checked out in data 1 . The investigation into outliers showed that all the participants' standard $Z$ scores were between the range -2.65 and 2.14 , and thus, between the range $\pm 3,29$, indicating the absence of outliers (Tabachnick \& Fidell, 2007). In addition, the analysis of box graph demonstrated there were not outliers. Multivariate outliers were scanned with Mahalanobis distance, and no outlier was identified. Examination on normal distribution revealed that skewness and kurtosis values were -.10 and -.19, respectively, showing that they were between the range \pm 1 . Furthermore, the division results of the skewness and kurtosis values to their standard errors were -.52 and -.53 , respectively. These values did not surpass the critical range \pm 1.96 values. The analysis of the histogram graphic at this stage unraveled that it had normal distribution values. Normality assumption was also measured by Kolmogrov-Smirnov analysis, resulting in reaching the decision that the data had normal distribution in view of the insignificance of the statistics ( $p>0.05)$ (Çokluk et al., 2014). In order to check the multivariate normality assumption of the items, Mardia's test was administered through MVN package (Korkmaz et al., 2014) from the R software (R Core Team, 2021). The Mardia skewness and kurtosis were detected to be different from normal distribution $(\mathrm{p}<.001)$. Since the multivariate normality assumption was not provided, Principal Axis Factoring extraction technique was selected for extraction (Fabrigar et al., 1999).

EFA was carried out using the responses of 180 students given to 16 item candidates in the scale to find out their dimensions. The sample size indicates the existence of a sufficient data set considering the suggestion of Kline (1994) and Bryman and Cramer (2001) as to gathering data 10 times bigger than the number of items (as cited in Çokluk et al., 2014). Barlett and Kaiser-Meyer-Olkin (KMO), two of the tests of sphericity, were conducted to be able to perform EFA. Following the appropriateness of the results, factor and the loadings of the items 
on the factor were discovered using Principal Axis Factoring method of EFA. To determine the number of factors, the results obtained from the analyses of eigenvalue, scree plot and parallel analysis methods (Timmerman \& Lorenza-Seva, 2011) were evaluated together. Since a singlefactor structure was identified, no rotation was used. Besides, Cronbach's Alpha and McDonalds' coefficient Omega were calculated. The stated analyses of item candidates were done by the psych package (Revelle, 2020) on the software programs R (R Core Team, 2021), SPSS 25 and on Factor 10.5 (Lorenza-Seva \& Ferrando, 2006).

Data 2 was exposed to CFA using Lisrel software v. 8.8 (Jöreskog \& Sörbom, 2006) to confirm the scale, the factor of which was determined by EFA. It was expected to establish model-data fit at this stage. To that end, in addition to calculating Root Mean Square Error of Approximation (RMSEA) value, Comparative Fit Index (CFI), Standardized Root Mean Square Residual (SRMR) indices, recommended by Kline (2015), $\chi^{2} / \mathrm{sd}$, Normed Fit Index (NFI), Goodness of Fit Index (GFI) values were calculated. If the $\chi^{2} / \mathrm{sd}$ value is smaller than 2 , it indicates the perfect fit and if it is $2-3$, it signifies good fit. Providing RMSEA and SRMR values are smaller than .05 , it indicates perfect fit, and if it is between .05-.08, it means there is mediocre fit (Browne \& Cudeck, 1993). If CFI, NFI and GFI fit indices are bigger than .95, it points to high fit, and if they are between .95-.90, it indicates acceptable fit (Çokluk et al., 2014; Hu \& Bentler, 1999; Tabachnick \& Fidell, 2007). On the condition that the fit indices are at desired levels, it will be shown that the structure that is tested is confirmed.

As well as the factor analyses, the difference in the level of self-efficacy of the first- and fourthyear students studying at the same department, which is assumed to be different from each other, was analyzed running independent samples t-test. The probable significant difference between the levels of reading self-efficacy of the first- and fourth-year students could be deemed to be evidence for construct validity.

To explore the stability of the confirmed scale, data 3 was collected from the same sample through test-retest. The analysis of Pearson correlation coefficient between the test and the retest will enable the investigation of the reliability of the scale results.

\section{FINDINGS}

In this section, results of the validity of the scale (content and construct validity), EFA and CFA, and reliability (internal consistency and stability) analyses have been presented.

\subsection{Findings Regarding the Validity Analyses}

In this section, results of the validity of the scale (content and construct validity), EFA and CFA, and reliability (internal consistency and stability) analyses will be presented.

\subsubsection{Content validity}

As was mentioned in the methodology section, the generated 16 items were e-mailed to three pre-service English language teacher educators teaching the courses of Reading Skills and Critical Reading and Writing to make sure the items catered for unearthing college students' level of reading self-efficacy. The three teacher educators contended that all the items could contribute to the measurement of reading self-efficacy of college students, and therefore, there was no need to exclude any items from the scale.

\subsection{2. $E F A$}

After testing the assumptions necessary for performing EFA and seeing that they were met, Barlett and Kaiser-Meyer-Olkin (KMO) analyses were carried out so as to check out the appropriateness of the data for factor analysis, the findings of which are given in Table 1 below. 
Table 1. Results of barlett and kaiser-meyer-olkin (KMO) analyses.

\begin{tabular}{lcc}
\hline Statistic & & Value \\
\hline Kaiser-Meyer-Olkin Measure of Sampling Adequacy & & .861 \\
Bartlett's Test of Sphericity & $\chi^{2}$ & 1170.25 \\
& $d f$ & 120 \\
& $p$ & .000 \\
\hline
\end{tabular}

Table 1 displays that data 1 was appropriate for factor analysis in view of the fact that the attained value was between .8-9 (Çokluk et al., 2014). Likewise, because Bartlett's Test of Sphericity was significant, it indicated the data could be factorized (Tabachnick \& Fidell, 2007); as a result, EFA was performed.

The analyses of eigenvalues, scree plot and parallel analysis methods (Timmerman \& LorenzaSeva, 2011) were done to determine the number of construct/s measured by the scale. The number of factors was ascertained in light of the findings in Figure 1 and Table 2.

Figure 1. Scree plot.

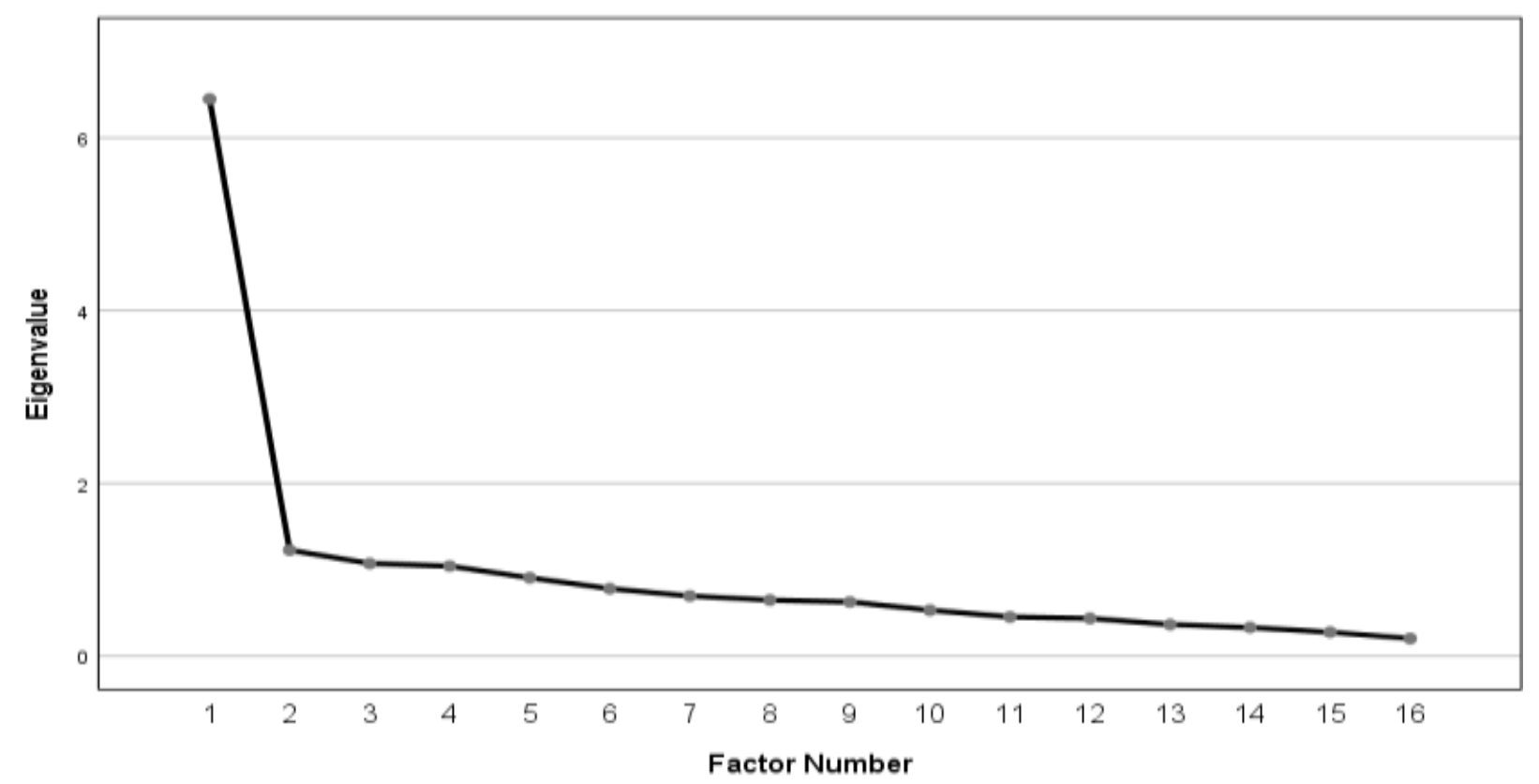

Taking into account Figure 1 demonstrating the eigenvalue of the factors determined by running EFA, it was induced that the scale had one dimension in that the slope took on almost a horizontal shape with the second factor.

Table 2. Results of EFA with respect to the number of factors.

\begin{tabular}{lcccc}
\hline Factor & Eigenvalue & $\begin{array}{c}\text { Exploratory } \\
\text { variance }\end{array}$ & $\begin{array}{c}\text { Parallel } \\
\text { Analysis Real } \\
\text { Data Variance }\end{array}$ & $\begin{array}{c}\text { Parallel Analysis } \\
\text { Random Variance }\end{array}$ \\
\hline 1 & 6.45 & 40.31 & 45.7 & 12.8 \\
2 & 1.22 & 7.65 & 8.2 & 11.6 \\
3 & 1.07 & 6.68 & 7.2 & 10.6 \\
4 & 1.04 & 6.49 & 6.2 & 9.7 \\
\hline
\end{tabular}


As depicted in Table 2, 16-item scale had four factors whose eigenvalues surpass 1. Considering the probability that more factors than the ones existing in reality could be extracted on the condition that eigenvalue is more than 1 , the eigenvalues of consecutive potential factors were compared. Whereas the eigenvalue of the first factor was 5.29 times more than that of the second factor, this value decreased to 1.14 in the next consecutive factor, which also showed that the scale was a unidimensional-scale. The findings obtained from conducting parallel analysis developed by Timmerman and Lorenza-Seva (2011) revealed that the real data variance was bigger than the random variance solely in the first factor, and in the other variances, it was smaller. This finding also suggested the scale was one-dimensional. When the findings obtained from all the methods were evaluated together, it was concluded that the scale had one dimension. It was also revealed that the factor explained $40 \%$ of the total variance.

Following taking the decision that the scale had one dimension, EFA was re-conducted for the one-dimensional situation and the factor loadings of the items on the dimension were calculated, which are given in Table 3 below.

Table 3. Factor loadings of the items on the dimension.

\begin{tabular}{lc}
\hline Item & Factor Loading \\
\hline 14 & .710 \\
13 & .685 \\
02 & .662 \\
16 & .661 \\
01 & .660 \\
11 & .652 \\
09 & .618 \\
04 & .598 \\
06 & .593 \\
5 & .557 \\
12 & .555 \\
7 & .543 \\
15 & .538 \\
08 & .537 \\
03 & .523 \\
10 & .514 \\
\hline
\end{tabular}

Table 3 shows that the loadings of the items on the factor varied between $.51-.71$. These values were above the critical loading values, .32 (Tabachnick \& Fidell, 2007) and .4 (Kim-Yin, 2004, as cited in Çokluk et al., 2014), mentioned in the literature. Therefore, loadings of the factors were ensured over .5 as outlined by Hair et al. (2019). For this reason, it is decided that none of the items would be excluded from the scale.

\subsection{3. $C F A$}

CFA was performed in an attempt to confirm the construct of the scale, figured out by virtue of EFA. The findings with respect to the CFA performed on data 2, different from data 1, are presented in Figure 2 and Table 4 below. 
Table 4. Goodness of fit indices of the scale.

\begin{tabular}{lcccc}
\hline Statistics & $\begin{array}{c}\text { Before } \\
\text { Modification }\end{array}$ & After Modification & Related Range & Meaning \\
\hline$\chi^{2} / \mathrm{sd}$ & 2.57 & 1.86 & $<2$ & Perfect fit \\
RMSEA & .1 & .0755 & $.05<$ RMSEA $<.08$ & Acceptable \\
SRMR & .059 & .051 & $.05<$ SRMR $<.08$ & Good fit \\
CFI & .96 & .98 & CFI $>.95$ & Perfect fit \\
NFI & .93 & .95 & NFI $\geq .95$ & Perfect fit \\
GFI & .82 & .87 & GFI $<.9$ & Weak fit \\
\hline
\end{tabular}

As depicted in Table 4, out of a total of six fit indices, perfect fit was observed in three indices, with 1.86 , which is lower than 2 in $\chi^{2}$ sd statistics, with 98 in CFI and .95 showing an equal value of the .95 cut-off in NFI statistics. Acceptable fit was observed within the range of .05 and .08 in RMSEA statistics with an index value of .075. Good fit was observed with .051 falling into the range between .05 and .08 in SRMR statistics while the weak fit was only seen in GFI statistics with a value of .87, which is lower than .9. Since the GFI value was close to good fit value and the expected values were provided by the other indices, it can be concluded that the model-data fit was ensured in data 2, and the construct determined by the EFA was verified by the CFA.

Figure 2. Factor loadings of the items revealed by CFA results.

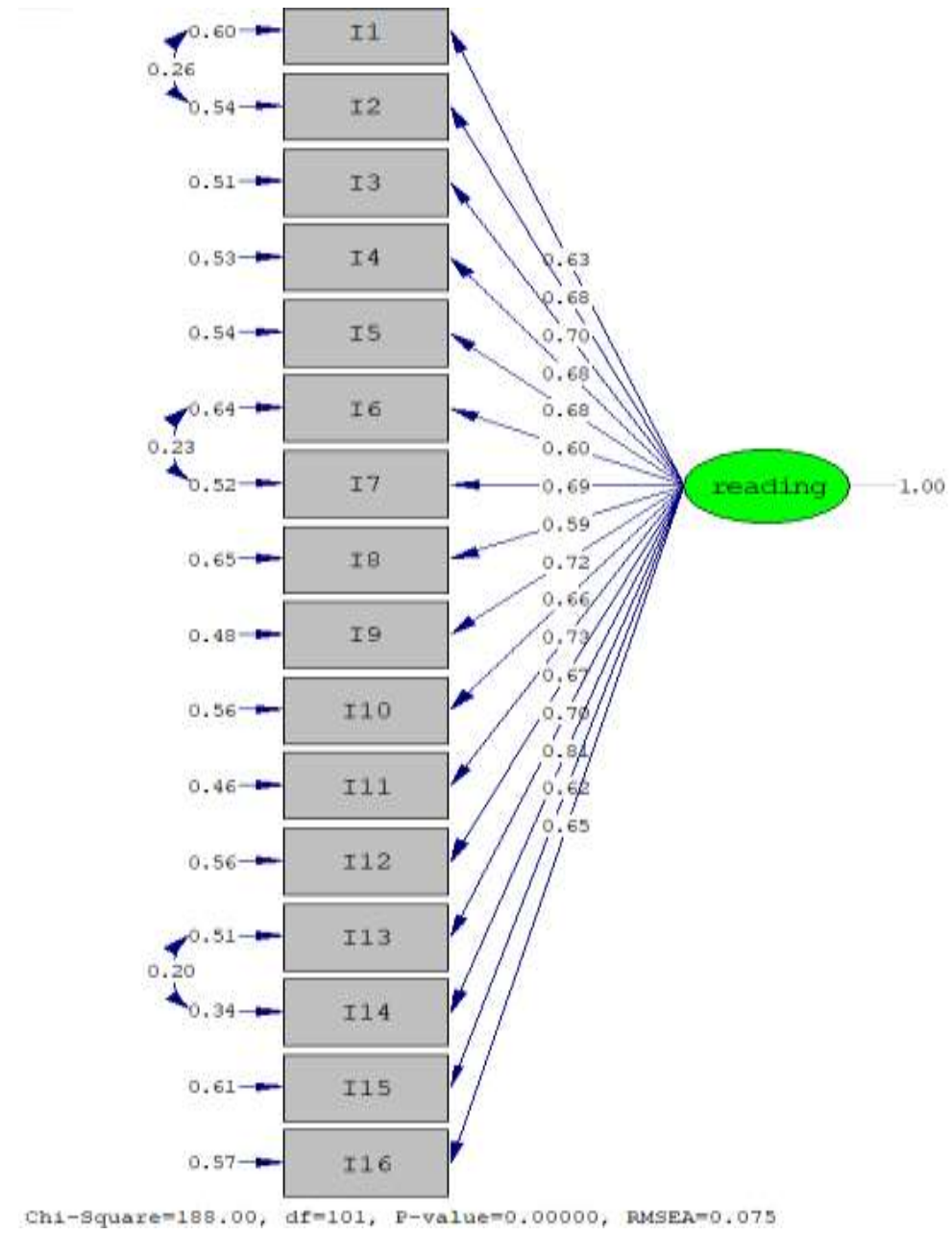


As demonstrated in Figure 2, the factor loadings of all the items were above .4. Seeing that factor loading $t$ values of all the items were $p=0.01$, surpassing the critical value 2.56, it was confirmed that their existence in the scale was significant. Analyzing the modification suggestions produced by the software program, error covariance was determined for the items 1 and 2, items 6 and 7, and items 13 and 14, involving similar expressions. The other modifications were not carried out as they were not grounded upon theoretical basis. Modeldata fit indices of the scale tested by CFA are given in Table 4 below.

The analysis of the construct validity was completed analyzing the total scores and correlation of the items, displayed in Table 5 below.

Table 5. Total scores and correlation of the items.

\begin{tabular}{lcc}
\hline Item & Corrected Item-Total Correlation & Cronbach's Alpha if Item Deleted \\
\hline 1 & .622 & .891 \\
2 & .625 & .891 \\
3 & .494 & .895 \\
4 & .559 & .893 \\
5 & .523 & .894 \\
6 & .558 & .893 \\
7 & .514 & .895 \\
8 & .510 & .895 \\
9 & .590 & .892 \\
10 & .489 & .896 \\
11 & .619 & .891 \\
12 & .530 & .894 \\
13 & .645 & .890 \\
14 & .669 & .889 \\
15 & .502 & .896 \\
16 & .630 & .891 \\
\hline
\end{tabular}

Table 5 illustrates that the total scores of the items with their correlation coefficients changed between .489-.669. Because all the values were bigger than .3 (Field, 2009), it is deduced that all the items were closely related to the construct.

The findings obtained from the analysis of data 3 conducted to compare the level of selfefficacy of the first- and fourth-year students are presented in Table 6.

Table 6. The independent t-test results of the difference in the level of the first-and fourth-year students' reading self-efficacy.

\begin{tabular}{llcccc}
\hline Group & $N$ & Mean & $S D$ & $t$ & $p$ \\
\hline First-year & 30 & 58.03 & 10.36 & -4.436 & .000 \\
Fourth-year & 35 & 68.60 & 8.84 & & \\
\hline
\end{tabular}

Table 6 shows that the level of fourth-year participants' reading self-efficacy was statistically higher than that of fourth-year participants' reading self-efficacy. Taking into consideration the point that it is something expected, it could be concluded that the scale accurately measures the construct.

\subsection{Findings Regarding the Reliability}

In view of the Cronbach's Alpha internal consistency coefficient obtained from data 1 was .90 . This finding exhibits this scale has a high level of internal consistency (George \& Mallary, 
2003). McDonalds' Omega coefficient, another reliability measurement method, performed on data 1 was .90. This finding shows that the scale as a whole has a high level of reliability. Furthermore, when Table 5 is interpreted in regard to the effect of the items on reliability, it could be seen that the exclusion of each item reduced the reliability. This might be viewed as the positive influence of the items on reliability. Lastly, the stability coefficient of the scale was revealed to be .76 through employing the test-retest method in data 3 over a time interval of two weeks, indicating a high level of relationship. In this regard, the scale has an adequate level of stability.

\section{DISCUSSION and CONCLUSION}

The findings obtained from EFA indicated the appropriateness of the data for carrying out factor analysis, and that the reading self-efficacy scale had only one dimension. Another finding yielded from EFA is linked with the factor loadings of the items on the dimension, suggesting exclusion of any of the items from the scale was unnecessary. CFA results showed that all the items in the scale were significant and closely related to the construct and confirmed the construct figured out by EFA.

Collecting data from the students of the departments of English language teaching and English language and literature at different years of study afforded an opportunity to the researchers to investigate whether or not there is a statistically significant difference between the levels of reading self-efficacy of the first- and fourth-year students, which also functioned as a medium for checking out if the scale served for measuring the construct. The findings obtained from independent-samples t-test analysis revealed the existence of a statistically significant difference between the levels of first- and fourth-year students' reading self-efficacy, providing strong evidence for the result that the scale measured the construct. The findings on Cronbach's Alpha internal consistency coefficient and McDonalds' Omega coefficient values showed that the developed scale had a high level of internal consistency and reliability. The finding on the stability coefficient value of the scale demonstrated that it has an adequate level of stability.

This study set out to fill the gap in the literature in developing and validating a reading selfefficacy scale through collecting data from the students at different years of study in the departments of English language teaching and English language and literature. The developed and validated five-point Likert reading self-efficacy scale differs from the ones existing in the literature considering the number of the collected data (Ahmadian \& Pasand, 2017; Boakye, 2015; Burrows, 2012; Kakaew, \& Damnet, 2017; McLean, \& Poulshock, 2018; Mullins, 2018; Zare \& Davoudi Mabarakeh, 2011), the comprehensiveness of the items directly related to reading self-efficacy as opposed to other scales (Boakye, 2015; Kakaew \& Damnet, 2017). Additionally, as opposed to the previously developed scales (Boakye, 2015; Kakaew \& Damnet, 2017), the items in this scale have been produced in accord with Bandura's (1997, 2006) principles of generating items in a reading self-efficacy scale. Thereupon, it could be argued that this study is highly likely to enable appropriately measuring reading self-efficacy of college students. Nevertheless, it should be noted that it could be adapted for measuring the level of L2 reading self-efficacy of students of different ages and at different levels of education although the reading self-efficacy scale was developed and validated through gathering data from college students. Moreover, using the reading self-efficacy scale could help identify students' strengths and weaknesses in their reading skills, which could enable reading teachers to become conscious of the areas to be developed in students' reading abilities. Considering the importance of being aware of what should be improved, the data to be provided by the scale can lead the teacher to properly scaffold their students to enhance their reading comprehension, and in turn, to increase the level of their reading self-efficacy. In view of the comprehensiveness of the items in the scale, it could be suggested it be adapted to measure younger students' reading self-efficacy. 


\section{Acknowledgments}

We would like to thank all the students participating in this study.

\section{Declaration of Conflicting Interests and Ethics}

The authors declare no conflict of interest. This research study complies with research and publishing ethics. The scientific and legal responsibility for manuscripts published in IJATE belongs to the author(s). Ethics Committee Number: Hatay Mustafa Kemal University Social and Human Sciences Research and Publication Ethics Board (Document numbered 902-01-FR 006 and dated October 1, 2020).

\section{Authorship Contribution Statement}

Gulten Kosar: Structuring the research, collecting data and writing the original draft. Yunus Emre Akbana: Finding resources, collecting data and revising the draft. Levent Yakar: Analyzing the data.

\section{Orcid}

Gulten Kosar iD https://orcid.org/0000-0002-4687-4382

Yunus Emre Akbana (D) https://orcid.org/0000-0002-5707-3564

Levent Yakar (iD https://orcid.org/0000-0001-7856-6926

\section{REFERENCES}

Afflerbach, P., \& Cho, B.Y. (2010). Determining and describing reading strategies: Internet and traditional forms of reading. In H.S. Waters \& W. Schneider (Eds.), Metacognition, strategy use, and instruction (pp. 201-225). Guilford.

Ahmadian, M., \& Pasand, P.G. (2017). Efl learners' use of online metacognitive reading strategies and its relation to their self-efficacy in reading. Reading Matrix: An International Online Journal, 17(2), 117-132. http://mail.readingmatrix.com/files/17097to04m.pdf

Bağc1, H. (2019). An investigation of Turkish language and Turkish language and literature teacher candidates' critical reading self-efficacy (The case of Mehmet Akif Ersoy University). Advances in Language and Literary Studies, 10(4), 14-20. http://dx.doi.org/10.7575/aiac.alls.v.10n.4p.14

Barber, A.T., Buehl, M.M., Kidd, J.K., Sturtevant, E.G., Nuland, L.R., \& Beck, J. (2015). Reading engagement in social studies: Exploring the role of a social studies literacy intervention on reading comprehension, reading self-efficacy, and engagement in middle school students with different language backgrounds. Reading Psychology, 36(1), 31-85. https://doi.org/10.1080/02702711.2013.815140

Bandura, A. (1997). Self-efficacy: The exercise of control. Freeman.

Bandura, A. (2006). Guide for constructing self-efficacy scales. In F. Pajares, \& T. Urdan (Eds.), Self-efficacy beliefs of adolescents (pp. 307-337). Information Age Publishing.

Barkley, J.M. (2006). Reading education: is self-efficacy important? Reading Improvement, 43(4), 194-211. https://eric.ed.gov/?id=EJ765527

Blachowicz, C., \& Ogle, D. (2008). Reading comprehension: Strategies for independent learners. The Guilford Press.

Boakye, N.A.N.Y. (2015). The relationship between self-efficacy and reading proficiency of first-year students: An exploratory study. Reading \& Writing: Journal of the Reading Association of South Africa, 6(1), 1-9. https://doi.org/10.4102/rw.v6il.52

Browne. M.W., \& Cudeck, R. (1993). Alternative ways of assessing model fit. In K. A. Bollen \& J. S. Long (Eds.), Testing structural equation models (pp. 136-162). Sage. 
Burrows, L. (2012). The effects of extensive reading and reading strategies on reading selfefficacy [Unpublished Doctoral dissertation, Temple University]. http://dx.doi.org/10.34 944/dspace/868

Butterworth, J., \& Thwaites, G. (2013). Thinking skills critical thinking and problem solving. Cambridge University Press.

Caprara, G.V., Fida, R., Vecchione, M., Del Bove, G., Vecchio, G.M., Barbaranelli, C., Bandura, A. (2008). Longitudinal analysis of the role of perceived self-efficacy for selfregulated learning in academic continuance and achievement. Journal of Educational Psychology, 100(3), 525-534. https://doi.org/10.35569/biormatika.v6i02.773

Carroll, J.M., \& Fox, A.C. (2017). Reading self-efficacy predicts word reading but not comprehension in both girls and boys. Frontiers in Psychology, 7, 2056. 1-9. https://doi.org/10.3389/fpsyg.2016.02056

Carter, C.E. (2011). Mindscapes: Critical reading skills and strategies. Cengage Learning.

Cho, E., Roberts, G.J., Capin, P., \& Roberts, G. (2015). Cognitive attributes, attention, and selfefficacy of adequate and inadequate responders in a fourth grade reading intervention. Learning Disabilities Research \& Practice, 30(4), 159-170. https://doi.org/10.1111/ldrp .12088

Çokluk, Ö., Şekercioğlu, G., \& Büyüköztürk, Ş. (2014). Sosyal bilimler için çok değişkenli istatistik SPSS ve LISREL uygulamalarl [Multivariate statistics for social sciences: SPSS and LISREL applications] (3rd ed.). Pegem Akademi.

Dallon, B., \& Ratner, W. (2002). Reading between the lines: Improve your scores on English \& social studies tests. Learning Express, LLC.

Duke, N.K., \& Pearson, P.D. (2002). Effective practices for developing reading comprehension. In A. E. Farstrup \& S.J. Samuels (Eds.), What research has to say about reading instruction (3rd ed., pp. 205-242). International Reading Association.

Fabrigar, L.R., Wegener, D.T., MacCallum, R.C., \& Strahan, E.J. (1999). Evaluating the use of exploratory factor analysis in psychological research. Psychological Methods, 4(3), 272. https://doi.org/10.1037/1082-989X.4.3.272

Ferrara, S.L.N. (2007). Reading fluency and self-efficacy: A case study. International Journal of Disability, Development and Education, 52(3), 215-231. https://doi.org/10.1080/1034 9120500252858

Forzani, E., Leu, D.J., Yujia Li, E., Rhoads, C., Guthrie, J.T., \& McCoach, B. (2021). Characteristics and validity of an instrument for assessing motivations for online reading to learn. Reading Research Quarterly, 56(4), 1-20, https://doi.org/10.1002/rrq.337

Fung, D., \& Macaro, E. (2019). Exploring the relationship between linguistic knowledge and strategy use in listening comprehension. Language Teaching Research. 1-25. https://doi.org/10.1177/1362168819868879

George, D., \& Mallery, P. (2003). SPSS for Windows step by step: A simple guide and reference. (11.0 update) (4th ed.). Allyn \& Bacon.

Ghonsooly, B., \& Elahi, M. (2010). Learners' self-efficacy in reading and its relation to foreign language reading anxiety and reading achievement. Journal of English Language Teaching and Learning, 53(217), 45-67. https://www.sid.ir/FileServer/JE/13232010217 03.pdf

Grabe, W., \& Stoller, F. (2002). Teaching and researching reading. Pearson Education.

Grabe, W., \& Stoller, F. L. (2019). Teaching and researching reading. Routledge.

Guthrie, J.T., \& Taboada, A. (2005). Fostering the cognitive strategies of reading comprehension. In J.T. Guthrie, A. Wigfield, \& K.C. Perencevich (Eds.), Motivating reading comprehension: Concept-oriented reading instruction (pp. 87-113). Lawrence Erlbaum Associates, Inc. 
Guthrie, J.T., Wigfield, A., \& VonSecker, C. (2000). Effects of integrated instruction on motivation and strategy use in reading. Journal of Educational Psychology, 92(2), 331341. https://doi.org/10.1037/0022-0663.92.2.331

Graham, S., Woore, R., Porter, A., Courtney, L., \& Savory, C. (2020). Navigating the challenges of L2 reading: Self-efficacy, self-regulatory reading strategies, and learner profiles. The Modern Language Journal, 104(4), 693-714. https://doi.org/10.1111/modl .12670

$\mathrm{Gu}$, Y. (2019). Approaches to learning strategy instruction. In A. U. Chamot \& V. Harris (Eds.), Learning strategy instruction in the language classroom: Issues and implementation (pp. 22-37). Multilingual Matters.

Hair, J.F., Anderson, R.E., Tatham, R.L., \& Black, W.C. (2019). Multivariate data analysis (8th ed.). Prentice Hall, Inc.

Hedges, J.L., \& Gable, R. (2016). The relationship of reading motivation and self-efficacy to reading achievement. $K-12$ Education, 31(1). https://scholarsarchive.jwu.edu/k12 ed/31

Hu, L.T., \& Bentler, P.M. (1999). Cutoff criteria for fit indexes in covariance structure analysis: Conventional criteria versus new alternatives. Structural equation modeling: $A$ Multidisciplinary Journal, 6(1), 1-55. https://doi.org/10.1080/10705519909540118

Jöreskog, K.G., \& Sörbom, D. (2006). LISREL 8.8 for windows [Computer software]. Scientific Software International.

Kakaew, J., \& Damnet, A. (2017). Learning strategies model to enhance Thai undergraduate students' self-efficacy beliefs in EIL textual reading performance. Advances in Language and Literary Studies, 8(6), 19-27. http://dx.doi.org/10.7575/aiac.alls.v.8n.6p.19

Karabay, A. (2013). Eleştirel okuma özyeterlik alg1 ölçeğinin geliştirilmesi [The development of critical reading self-efficacy perception scale]. Turkish Studies - International Periodical For The Languages, Literature, and History of Turkish and Turkic, 8(13), 1107-1122. http://dx.doi.org/10.7827/TurkishStudies.5389

Kintsch, W. (1998). Comprehension: A paradigm for cognition. Cambridge.

Kline, R.B. (2015). Principles and practice of structural equation modeling. Guilford publications.

Kula, S.S., \& Budak, Y. (2020). Self-efficacy perceptions scale for reading comprehension of 4th grade students in primary school: Validity and reliability study. Bartın University Journal of Faculty of Education, 9(1), 106-120. http://dx.doi.org/10.14686/buefad.5368 $\underline{85}$

Li, Y., \& Wang, C. (2010). An empirical study of reading self-efficacy and the use of reading strategies in the Chinese EFL context. Asian EFL Journal, 12(2), 144-162. http://70.40.196.162/PDF/June-2010.pdf\#page=144

Lorenzo-Seva, U., \& Ferrando, P.J. (2006). FACTOR: A computer program to fit the exploratory factor analysis model. Behavioral Research Methods, Instruments and Computers, 38(1), 88-91. https://doi.org/10.3758/BF03192753

Macaro, E. (2019). Language learner strategies and individual differences. In A. U. Chamot \& V. Harris (Eds.), Learning strategy instruction in the language classroom: Issues and implementation (pp. 68-80). Multilingual Matters. https://doi.org/10.21832/9781788923 $\underline{415-011}$

McGuinness, D. (2005). Language development and learning to read. The MIT Press.

McLean, S., \& Poulshock, J. (2018). Increasing reading self-efficacy and reading amount in efl learners with word-targets. Reading in a Foreign Language, 30(1), 76-91. https://files.eric.ed.gov/fulltext/EJ1176293.pdf

Meniado, J.C. (2016). Metacognitive reading strategies, motivation, and reading comprehension performance of Saudi EFL students. English Language Teaching, 9(3), 117-129. http://dx.doi.org/10.5539/elt.v9n3p117 
Mills, N., Pajares, F., \& Herron, C. (2006). A reevaluation of the role of anxiety: Self-efficacy, anxiety, and their relation to reading and listening proficiency. Foreign Language Annals, 39(2), 276-295. https://doi.org/10.1111/j.1944-9720.2006.tb02266.x

Mullins, L.A. (2018). Personalized texts and second language reading: A study in self-efficacy. [Unpublished Doctoral dissertation, Georgia State University]. https://scholarworks.gsu. edu/mse diss $/ 70 /$

Mullins, L.A. (2019). Evaluating target language reading self-efficacy scales: Applying principles gleaned from Bandura's writings. Reading Matrix: An International Online Journal, 19(2), 1-12. http://www.readingmatrix.com/files/21-1jkbwrqn.pdf

Murad Sani, A., \& Zain, Z. (2011). Relating adolescents' second language reading attitudes, self efficacy for reading, and reading ability in a non-supportive ESL setting. The Reading Matrix, 11(3), 243-254. http://www.readingmatrix.com/articles/september_2011/sani z ain.pdf

Palincsar, A.S., \& Brown, A.L. (1986). Interactive teaching to promote independent learning from text. The Reading Teacher, 39(8), 771-777. http://www.jstor.org/stable/20199221

Peura, P.I., Viholainen, H.J., Aro, T.I., Räikkönen, E.M., Usher, E.L., Sorvo, R.M., ... \& Aro, M.T. (2019). Specificity of reading self-efficacy among primary school children. The Journal of Experimental Education, 87(3), 496-516. https://doi.org/10.1080/002209 73.2018.1527279

R Core Team. (2021). R: A language and environment for statistical computing [Computer software manual]. R foundation for statistical computing. https://www.R-project.org/

Revelle, W. (2020). Psych: procedures for personality and psychological research (Version 2.1.9) [Computer software] https://cran.r-project.org/web/packages/psych/index.html

Ronimus, M., Eklund, K., Westerholm, J., Ketonen, R., \& Lyytinen, H. (2020). A mobile game as a support tool for children with severe difficulties in reading and spelling. Journal of Computer Assisted Learning, 36(6), 1011-1025. https://doi.org/10.1111/jcal.12456

Schunk, D.H. (2003). Self efficacy for reading and writing: Influence of modeling, goal-setting and self-evaluation. Reading and Writing Quarterly, 19(2), 159-172. https://doi.org/10.1 $\underline{080 / 10573560308219}$

Smith, F. (2012). Understanding reading: A psycholinguistic analysis of reading and learning to read. Routledge.

Soland, J., \& Sandilos, L.E. (2020). English language learners, self-efficacy, and the achievement gap: understanding the relationship between academic and social-emotional growth. Journal of Education for Students Placed at Risk (JESPAR), 26(1), 1-25. https://doi.org/10.1080/10824669.2020.1787171

Solheim, O.J. (2011). The impact of reading self-efficacy and task value on reading comprehension scores in different item formats. Reading Psychology, 32(1), 1-27. https://doi.org/10.1080/02702710903256601

Şahin, E., \& Öztahtalı, İ. (2019).Etkili okuma özyeterlik alg1 ölçeğinin geliştirilmesi: geçerlilik ve güvenirlik çalişmasi [The development of effective reading self efficacy perception scale: study on the validity and reliability]. Electronic Turkish Studies, 14(4). http://dx.doi.org/10.29228/TurkishStudies.23378

Tabachnick, B.G., \& Fidel, L.S. (2007). Using multivariate statistics (5th ed.). Pearson.

Tavakoli, H., \& Koosha, M. (2016). The effect of explicit metacognitive strategy instruction on reading comprehension and self-efficacy beliefs: The case of Iranian university EFL students. Porta Linguarum, 25, 119-133. https://dialnet.unirioja.es/descarga/articulo/541 2447.pdf

Taylor, A.M. (2014). L1 glossing and strategy training for improving L2 reading comprehension: A meta-analysis. International Journal of Quantitative Research in Education, 2(1), 39-68. https://doi.org/10.1504/IJQRE.2014.060973 
Timmerman, M.E., \& Lorenzo-Seva, U. (2011). Dimensionality assessment of ordered polytomous items with parallel analysis. Psychological Methods, 16(2), 209-220. https://doi.org/10.1037/a0023353

Tremblay, P.F., \& Gardner, R.C. (1995). Expanding the motivation construct in language learning. The Modern Language Journal, 79(4), 505-518. https://doi.org/10.1111/j.154 0-4781.1995.tb05451.x

Unrau, N.J., Rueda, R., Son, E., Polanin, J.R., Lundeen, R.J., \& Muraszewski, A.K. (2018). Can reading self-efficacy be modified? A meta-analysis of the impact of interventions on reading self-efficacy. Review of Educational Research, 88(2), 167-204. https://doi.org/1 $\underline{0.3102 / 0034654317743199}$

Venegas, E.M. (2018). Strengthening the reader self-efficacies of reluctant and struggling readers through literature circles. Reading \& Writing Quarterly, 34(5), 419-435. https://doi.org/10.1080/10573569.2018.1483788

Zare, M., \& Davoudi Mobarakeh, S. (2011). The relationship between self-efficacy and use of reading strategies: The case of Iranian senior high school students. Studies in Literature and Language, 3(3), 98-105. http://dx.doi.org/10.3968/n

Zimmerman, B.J. (2013). From cognitive modeling to self-regulation: A social cognitive career path. Educational Psychologist, 48(3), 135-147. https://doi.org/10.1080/00461520.2013. $\underline{794676}$ 


\section{APPENDIX}

\section{Reading Self-Efficacy Questionnaire}

Reading self-efficacy questionnaire has been designed in order to measure your judgement of your reading self-efficacy. Please read the items in the questionnaire carefully and make an accurate evaluation of your reading self-efficacy by choosing the number that accurately represents your ability in each item. Remember to provide information about your age, department and gender.
Gender
: $\square$ Female
Male

Age

Department :

Year of study :

\begin{tabular}{|c|c|c|c|c|}
\hline 1 & 2 & 3 & 4 & 5 \\
Not at all & Slightly & Somewhat & Fairly well & Very well \\
\hline
\end{tabular}

\begin{tabular}{|l|l|l|l|l|l|}
\hline Item & $\mathbf{1}$ & $\mathbf{2}$ & $\mathbf{3}$ & $\mathbf{4}$ & $\mathbf{5}$ \\
\hline 1- I can identify the topic of a reading passage. & & & & & \\
\hline 2-I can identify the purpose of the author. & & & & & \\
\hline $\begin{array}{l}\text { 3-I can use my background knowledge about the topic of the } \\
\text { reading passage to improve my reading comprehension. }\end{array}$ & & & & & \\
\hline 4-I can find the explicit main idea of a reading passage. & & & & \\
\hline 5-I can find the implied main idea of a reading passage. & & & & \\
\hline 6-I can determine topic sentences in a reading passage. & & & & \\
\hline $\begin{array}{l}\text { 7-I can find supporting detail/s in a paragraph. } \\
\text { 8-I can use context clues to guess the meanings of unknown words } \\
\text { in a passage. }\end{array}$ & & & & & \\
\hline $\begin{array}{l}\text { 9-I can judge whether supporting details are relevant to the topic of } \\
\text { the reading passage. }\end{array}$ & & & & & \\
\hline 10-I can distinguish facts from opinions in a reading passage. & & & & & \\
\hline 11-I can answer questions on the passage after reading it. & & & & & \\
\hline $\begin{array}{l}\text { 12-I can use reading strategies like skimming and scanning to } \\
\text { enhance my reading comprehension. }\end{array}$ & & & & & \\
\hline 13-I can draw logical conclusions from a reading passage. & & & & & \\
\hline $\begin{array}{l}\text { 14-I can make logical inferences based on what is given in the } \\
\text { reading. }\end{array}$ & & & & & \\
\hline 15- I can take notes of key points as reading a passage. & & & & & \\
\hline 16-I can summarize a reading passage after reading it. & & & \\
\hline
\end{tabular}

